\title{
ELT for Peace Education: Negotiating Ethnic and Cultural Plurality
}

\author{
Piku Chowdhury \\ Satyapriya Roy College of Education \\ AA-287, Sector-1, Salt Lake, Kolkata-700064, West Bengal, India \\ E-mail: chowdhury.piku@yahoo.com
}

Doi:10.7575/aiac.alls.v.4n.1p.149

Received: 01/12/2012

URL: http://dx.doi.org/10.7575/aiac.alls.v.4n.1p.149

Accepted: 03/01/2013

\begin{abstract}
Multiculturalism and multi-ethnicity have assumed the status of the most charged signs characterizing social contingencies and resultant violence in the increasingly glocalized world today. Minoritization continually interrupts and interrogates the homogeneous, horizontal claim of the projected democratic liberal society. Solidarity turns out to be situational and strategic while the concept of commonality is negotiated through contingencies of social interest and political claims. As Homi K. Bhabha points out in "Cultures in Between"- "How did we allow ourselves to forget that the nationalist violence between Hindus and Muslims lie just under the skin of India's secular modernity? ...We have entered an anxious age of identity"(p.59). Experimenting with UNESCO's vision of promoting a "culture of peace" through education, 70 trainee teachers from varied socio-cultural and religious backgrounds were exposed to ELT exercises that opened up new avenues of peace education.
\end{abstract}

Keywords: Multiculturalism, Minoritization, Culture of peace, ELT

\section{Introduction}

Language teachers like all other fellow humans thrive and operate in hard times against a perpetually evolving contradictory set of values. The world is torn apart with terrorism, ethnic conflict, social inequality and violent resistance and teaching can no longer be segregated as a detached and passive transmission of age old paradigms and knowledge. Multiculturalism and multi-ethnicity have assumed the status of the most charged signs characterizing social contingencies and resultant violence. Minoritization continually interrupts and interrogates the homogeneous, horizontal claim of the projected democratic liberal society and its homogenous curriculums. Solidarity turns out to be situational and strategic while the concept of commonality is negotiated through contingencies of social interest and political claims. As Homi K. Bhabha points out in "Cultures in Between"- "How did we allow ourselves to forget that the nationalist violence between Hindus and Muslims lie just under the skin of India's secular modernity? ... We have entered an anxious age of identity" (p.59). English Language Teaching becomes a critical agency in this scenario homogenizing in philosophy and yet continually addressing covert interstitial paradigms. Teaching-learning in different contexts and at different levels, possesses contours and frontiers that are perennially interpenetrating and overlapping in a striking relativity with the social identities of the multi-ethnic and multicultural human elements, at a given time and context, remaining a locus of immense potentiality/possibilities. It continually refers to and engenders a sweeping variety of interacting agencies. The crisis emerges with the hegemony of a specific pedagogy, cardinally Western in essence, with scarce or no space for any other indigenous form of knowledge, being transmitted in various ways with an element of tough competition in what we call the global education market. The need to prepare the students for negotiating the plurality of ethno-cultural dimensions and associated beliefs and practices for a sustainable culture of peace emerges as a challenge.

The Declaration of the Ministers of Education participating in the forty-fourth session of the International Conference on Education voiced a call to mainstream education for a culture of peace:

Education policies have to contribute to the development of understanding, solidarity and tolerance among individuals and among ethnic, social, cultural and religious groups ...education should promote knowledge, values, attitudes and skills conducive to respect for human rights and to an active commitment to the defence of such rights and to the building of culture of peace and democracy... [it is imperative]to base education on principles and methods that contribute to the development of the personality of pupils and adults..to take suitable steps to establish in educational institutions an atmosphere contributing to the success of education for international understanding, so that they become ideal places for the exercise of tolerance, respect for human rights, the practice of democracy and learning about the diversity and wealth of cultural identities. 
Betty A. Reardon in her Education for a Culture of Peace defines peace as "a set of conditions in which diverse people share their common planet, cultivating mutually enhancing relationships, respecting the dignity and rights of all, appreciating the richness of their diversity while living in harmony with the natural environment", while the United Nations Document UN DOC. A/53/370, Oct. 1998, Article 2, depicts the Culture of Peace as "the transformation of violent competition into co-operation based on the sharing of values and goals" (p.7). The World Confederation of Organizations of the Teaching Profession (1989: 7), clearly states that its aims include the promotion of equality, peace, justice, freedom, and human rights among all peoples. The US organization, Educators for Social Responsibility, confirms the importance of the three Rs of traditional education — reading, 'riting and'rithmetic - but argues that we need to extend these to make "responsibility" the fourth $\mathrm{R}$ of education. The most significant attempt to deal with language teaching and world problems is UNESCO's linguapax project. The name comes from the Latin words lingua (language) and pax (peace) and refers to a series of seminars dealing with language teaching for international understanding. The first Linguapax conference, held in 1987 in Kiev, USSR, brought together such groups as the International Association of Applied Linguistics,International Association for the Development of Cross-cultural Communication,and World Federation of Modern Language Associations to discuss "Content and Methods of Teaching Foreign Languages and Literature for Peace and International Understanding."The resulting Linguapax Kiev Declaration made four recommendations to foreign-language teachers:

- Be aware of their responsibility to further international understanding through their teaching.

- Increase language teaching effectiveness so as to enhance mutual respect, peaceful coexistence, and cooperation among nations.

- Lay the basis for international cooperation through classroom cooperation using language-teaching approaches responsive to students' interests and needs.

Violence is conceived as the necessary outcome of a web of competitive and adversarial relationships that comprise the culture of war and wanton brutality in the name of development, and essentially a construct of human imagination like all other cultural institutions. The malady originates in the mind and hence, asserts the Preamble to the Constitution of UNESCO, 1945, the panacea should emerge from the mind itself: "Since wars begin in the minds of men, it is in the minds of men that the defences of peace must be constructed". Instances of an unwarranted fetishization of knowledge as a mental space following a hegemonic model erected by the West with total disregard for indigenous wisdom, leading to colossal failures of huge developmental plans and subsequent triggering of armed resistance and violent dissents, are only too many in the world today. "Global education" is a new approach to language teaching that attempts to answer these questions. It aims to enable students to effectively acquire a foreign language while empowering them with the knowledge, skills, and commitment required by world citizens to solve global problems. Fisher and Hicks(1985) defines global education as "education which promotes the knowledge, attitudes and skills relevant to living responsibly in a multicultural, interdependent world" (p. 8).

The idea that English-language teaching can contribute to creating a better world is not new. Indeed, much traditional language teaching makes vague references to global education ideals. . H. D. Brown (1990) asserts- "Global, peace and environmental issues intrinsically affect every human being on earth. These issues provide content for your contentbased humanized ESL teaching of the 90's. We teachers have a mission, a mission of helping everyone in this world communicate with each other to prevent the global disaster ahead. The 90's are in your hands". However, as Wilga Rivers (1968), a noted language educator points out, this has mostly remained wishful thinking:

It may be well to ask ourselves whether international understanding, let alone world peace, can be said to have been promoted by the considerable amount of foreign language teaching in the world. Diligent learning of foreign words and phrases, laborious copying and recitation of irregular verb paradigms,and the earnest deciphering of texts in the foreign language can hardly be considered powerful devices for the development of international understanding and good will.(p.262)

Teacher education assumes a critical role in this perspective. The in-service deputed teachers who would teach thousands of developing minds are crucial in developing a culture a peace and thus if they themselves lack clarity of perception and purpose ELT would remain a mechanical exercise in teaching a foreign language totally dissociated from the world. ELT exercises promoting peace education will have the characteristics of Conflict Resolution (in problem solving and negotiation activities) that may be taught in the steps outlined below:

1. Definition of the problem to be resolved

2. Information gathering phase

3. Processing and understanding information

4. Discussion and examination of a variety of solutions

5. Conciliation and negotiation

6. Negotiations

With this in view some core areas were identified on the basis of personal interviews of some trainee teachers. It was noted that majority of teachers suffer from a Western tendency of a fetishization of hegemonic artificial knowledge imposed by the Western model of education and tend to be intolerant and often contemptuous of local indigenous knowledge base often concealed in various practices and rituals. This not only creates insurmountable wall of cultural 
distinction and intolerance among the urban and rural professionals, but also segregates the urban trainees conditioned in Western concepts from the students from various socio-cultural backgrounds. English Language Teaching under such circumstances then becomes a mechanical exercise of linguistic forms and the very organic nature of the language that principally connects human souls remains defeated.

A particular rural local religious festival of the Hindus - the 'Gajan' was identified after interacting with the rural trainees and one of them was urged to describe the same in English to the whole class comprising of Muslim and Christian trainees from both urban and rural backgrounds. Then a selected group of urban non-Hindu trainees were grouped with some rural counterparts and assigned a project of visiting their locality and interact with the local rural school students to ferret out details of that popular local festival that they apparently found strictly religious and superstitious in flavor. They were made to work jointly as a team and submit a report in English. A study was conducted to find out the difference in attitude of the urban trainees who undertook the project and those who did not and the possible relation to their exposure to the indigenous essentially secular knowledge base with its practical and profound logic.

\section{Objectives}

The present study aims at exploring the roots of cultural and religious intolerance among trainee teachers and investigating whether a planned ELT exercise in the form of exposure to grass-root level customs and rituals of other religions has significant influence upon the attitude of the trainee teachers.

\section{Hypothesis}

The null hypothesis is as follows:

$\mathrm{H}_{0}$ : There is no influence of a planned exposure to indigenous rituals of other religions as a part of ELT in promoting tolerance and respect for members of other communities and rural backgrounds.

\section{Population and Sample}

Trainee teachers in B.Ed.colleges of West Bengal, from different religions and socio-cultural backgrounds constituted the population. The sample of 70 urban non-Hindu trainees was drawn through a randomized process.

\subsection{Variables}

(i) the urban teachers' exposure to rural indigenous Hindu religious ritual

(ii) the urban trainee teachers' attitude towards their Hindu rural counterparts

\section{Tools}

Questionnaires were prepared and checked by experts. Data was collected by distributing these questionnaires among the sample.

\section{Method}

The urban non-Hindu trainees were grouped with the Hindu rural peers who are not so proficient in English like their confident urban counterparts. Some such rural trainees were deputed teachers from schools of that village and adjoining area. Then the urban trainees were assigned a project of visiting the village where 'Gajan' is celebrated and many apparently peculiar rituals are observed. They were urged to work with their rural peers as a team and interact with Hindu village elders and local school students with the help of their peers to gather, process and comprehend the plethora of information on 'Gajan mela' as observed in the village and then try to realize the true significance and scientific principles behind the apparently superstitious rituals that they had laughed off contemptuously so far. Then they were urged to prepare a report in English collaboratively. On one hand the diffident rural trainees gained confidence in being a superior guiding position in the team and on the other hand the urban peers gained significant insight into the religious indigenous rituals. Questionnaires were distributed among the trainees before and after the project to assess changes in response.



1.1 Man piercing tongue with iron spear and man lying on sharp nails as part of Gajan ritual 


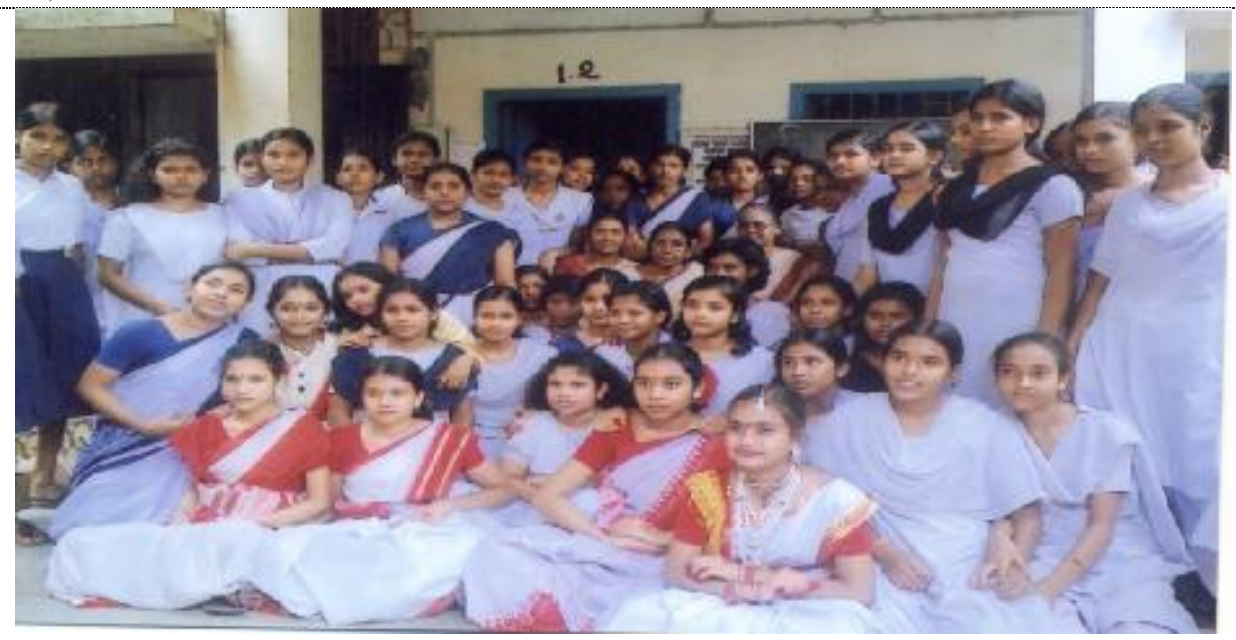

1.2 Village School visited by urban trainees

\section{Data Analysis}

Data collected from survey questionnaire have been classified as follows:

\begin{tabular}{|l|c|c|c|}
\hline & $\begin{array}{c}\text { No. of Urban } \\
\text { Trainees exposed to } \\
\text { the rural Project }\end{array}$ & $\begin{array}{c}\text { No. of urban trainees } \\
\text { not exposed to the } \\
\text { rural project }\end{array}$ & Total \\
\hline $\begin{array}{l}\text { No. of trainee teachers } \\
\text { enthusiastic towards } \\
\text { working together with their } \\
\text { rural Hindu peers }\end{array}$ & 28 & 11 & 39 \\
\hline $\begin{array}{l}\text { No. of trainee teachers not } \\
\text { willing to work together } \\
\text { with their rural Hindu } \\
\text { peers }\end{array}$ & 15 & 26 & 41 \\
\hline Total & 43 & 37 & 70 \\
\hline
\end{tabular}

The Chi-square test was applied to test the null hypothesis at $1 \%$ level of significance. The Chi-square value, computed based on the above data after applying Yate's correction for continuity was -

$\left[\{(28 \times 26-11 \times 15)-70 / 2\}^{2} \times 70\right] / 39 \times 41 \times 43 \times 37$

$=19514880 / 2544009$

$=7.671$ (rounded to 3 decimal places)

Tabulated value of Chi-Square with Degrees of Freedom 1, at $\alpha$-level $0.01=6.635$.

\section{Inference}

Since the computed chi-square value is greater than the tabulated value at $1 \%$ level, the null hypothesis is rejected and thus one has strong reason to believe that such an ELT exercise allowing trainee teachers to be exposed to different indigenous religious and cultural rituals in tandem with active interaction with multi ethnic communities does have influence on a teacher's enthusiasm towards embracing peers and students of different communities. As a necessary corollary such an ELT exercise also brings the otherwise shy marginalized rural community members into the limelight and help in promoting confidence and oneness with their more polished and proficient urban peers.

Focus on community controversies in tandem with prejudicial religious and socio-political beliefs must be incorporated into ELT praxis for ensuring prevention of communication gaps and ideological fissures that lead to dissidence and hatred. A culture of peace may then be achieved. Such ELT projects can involve different community members as allies as the throbbing of human values emerge from behind the veil of strange, apparently bizarre rituals and the urban complacency fizzles into the warmth of human relations. Trainee teachers gain valuable insight through such critical though provoking exercises that equip them better for the future classrooms comprising of young minds from a plurality of religious and ethnic backgrounds. Fear of a foreign tongue and shyness for poor communication skills in English melts into a new level of confidence and fellow feeling so essential for a truly sustainable culture of peace. 


\section{References}

Bamford, J. (1990). "Education and Action beyond the Classroom." The Language Teacher 14 (5).

Brooks, E. and L. Fox. 1995. Making Peace. New York: St. Martins Press.

Brown, H.D. (1990). On Track to Century 21. Plenary talk at TESOL '90, San Francisco.

Cates, K. (1990). “Teaching for a Better World." TheLanguage Teacher 14(5).

Fisher, S. and D. Hicks. (1985). World Studies 8-13. New York: Oliver \& Boyd.

Maley, A. (1992). "Global Issues in ELT.” Practical English Teaching 13 (2) .

Mark, K. (1993). “Some Thoughts about Global Content.”The Language Teacher 17(5).

Oura, A. et al. (1989). Cosmos English Course. Tokyo:Sanyusha.

Reardon, B. A. (2001) Education for a Culture of Peace in a Gender Perspective. Paris: UNESCO publishing.

Reischauer, E. (1973). Toward the 21st Century. New York:Knopf.

Rivers, W. (1968). Teaching Foreign Language Skills. Chicago: University of Chicago Press.

Rivers, W. (1968). Teaching Foreign Language Skills. Chicago:University of Chicago Press.

UNESCO. (1974). Recommendation Concerning Education for International Understanding, Cooperation and Peace and Education Relating to Human Rights and Fundamental Freedoms. Paris: UNESCO.

- 1987. Linguapax Kiev Declaration on "Content and Methods that could contribute in the Teaching of Foreign Languages and Literacy to International Understanding and Peace.” Paris: UNESCO. 